\title{
Analisis Pelayanan Kefarmasian Berdasarkan Indikator Pelayanan Pasien WHO pada Puskesmas Kecamatan yang Belum dan Sudah Terakreditasi di Kota Depok
}

\author{
Analysis of Pharmaceutical Care Based on WHO Patient Care at Sub District of \\ Community Health Centers Not Accredited and Accredited in Depok City
}

\author{
Makhdalena*, Mahdi Jufri, Retnosari Andrajati \\ Program Studi S2 Ilmu Kefarmasian, Fakultas Farmasi, Universitas Indonesia, Depok, Indonesia \\ E-mail: adakahut@gmail.com
}

Diterima:14 Maret 2018

Direvisi: 26 Juli 2018

Disetujui: 18 Agustus 2018

\begin{abstract}
Abstrak
Pelayanan kefarmasian berdasarkan indikator pelayanan pasien WHO di berbagai negara berkembang, termasuk Indonesia, belum memenuhi persyaratan. Akreditasi puskesmas diharapkan dapat meningkatkan pelayanan kefarmasian yang berdampak terhadap penggunaan obat rasional. Tujuan penelitian adalah menganalisis pelayanan kefarmasian berdasarkan indikator pelayanan pasien WHO pada semua puskesmas kecamatan (9 puskesmas belum terakreditasi dan 2 puskesmas sudah terakreditasi) di Kota Depok. Penelitian ini menggunakan rancangan potong lintang dan dilakukan pada bulan Desember 2016-Februari 2017. Sampel penelitian adalah pasien dewasa dari poli umum dan pasien pendamping dari poli manajemen terpadu balita sakit yang memenuhi kriteria inklusi, serta semua lembar resep obat yang dibawanya. Responden berjumlah 30 orang dan 30 resep setiap puskesmas kecamatan. Pengumpulan data dilakukan melalui wawancara dan observasi responden serta analisis lembar resepnya. Analisis data menggunakan uji Mann-whitney dan Chi-square. Hasil puskesmas kecamatan belum terakreditasi yang memenuhi rekomendasi WHO untuk waktu penyiapan dan penyerahan obat (>3 menit) sebesar 77,8\% dan yang sudah terakreditasi $100 \%$. Semua puskesmas kecamatan di Kota Depok tidak ada yang memenuhi rekomendasi WHO untuk kesesuaian penyerahan obat, pelabelan obat cukup dan pasien dengan pengetahuan obat yang benar $(=100 \%)$. Waktu penyiapan dan penyerahan obat pada puskesmas kecamatan sudah terakreditasi lebih lama secara bermakna dari yang belum terakreditasi $(\mathrm{p}<0,05)$. Kesesuaian penyerahan obat, pelabelan obat cukup, dan pengetahuan pasien tentang penggunaan obat yang benar antara puskesmas kecamatan yang belum dan sudah terakreditasi tidak berbeda bermakna $(p>0,05)$. Kesimpulan menunjukkan pelayanan kefarmasian berdasarkan indikator pelayanan pasien WHO pada puskesmas kecamatan yang terkareditasi secara umum tidak berbeda dengan yang belum terakreditasi.
\end{abstract}

Kata kunci: Akreditasi; Indikator pelayanan pasien WHO; Pelayanan kefarmasian; Puskesmas

\begin{abstract}
Pharmaceutical care based on WHO patient care indicators in various developing countries, including Indonesia, have not met the requirements. Puskesmas accreditation is expected to improve pharmaceutical care that has an impact on rational drug use. The purpose of the study was to analyze pharmacy care based on WHO patient care indicators in all sub-district health centers $(9$ health centers not yet accredited and 2 health centers already accredited) in Depok City. This study used a cross-sectional design and was carried out in December 2016-February 2017. The sample was adult patients from general poly and accompanying patients from integrated management of sick toddlers who met the inclusion criteria, as well as all prescription drugs taken. There were 30 respondents and 30 prescriptions for each sub-district health center. Data collection was done through interviews and observation of respondents and analysis of the recipe sheets. Data analysis used MannWhitney and Chi-square tests. The results show that the sub-district health centers have not been accredited which meets WHO recommendations for preparation time and delivery of drugs (> 3 minutes) of $77.8 \%$ and those who are $100 \%$ accredited. None of the sub-district health centers in Depok City meet WHO recommendations for the suitability of drug delivery, adequate drug labeling and patients with correct drug knowledge $(=100 \%)$. The time of preparation and delivery of drugs at the subdistrict health centers has been accredited significantly longer than those not yet accredited ( $p<0.05)$. The suitability of drug delivery, drug labeling is sufficient, and the patient's knowledge of correct drug use between puskesmas that have not been and have been accredited is not significantly different ( $p>0.05)$. The conclusions show pharmaceutical care based on WHO patient service indicators at sub-district health centers that are not different from those that have not been accredited
\end{abstract}

Keyword: Accreditation; WHO patient care indicator; Pharmaceutical care; Community health center 


\section{PENDAHULUAN}

Pelayanan kefarmasian yang merupakan bagian dari pelayanan kesehatan bertujuan untuk meningkatkan penggunaan obat yang rasional, keamanan penggunaan obat, efisiensi biaya obat dan meningkatkan kualitas hidup pasien. ${ }^{1}$ Penggunaan obat yang tidak rasional menyebabkan biaya kesehatan lebih tinggi dan kerugian pasien yang signifikan, yaitu kondisi pasien yang buruk dan kemungkinan terjadi reaksi obat yang tidak dikehendaki. ${ }^{2}$

Pelayanan kefarmasian adalah suatu tanggung jawab profesi apoteker dalam mengoptimalkan terapi dengan cara mencegah dan memecahkan masalah terkait obat. Pelayanan kefarmasian berperan meningkatkan penggunaan obat rasional yang akan menentukan keberhasilan pengobatan. $^{3}$

Pelayanan kefarmasian yang tidak rasional masih menjadi permasalahan di berbagai negara berkembang karena mengantarkan pada penggunaan obat yang tidak rasional. ${ }^{4}$ WHO telah menyusun tiga indikator utama penggunaan obat rasional, yaitu indikator peresepan, indikator pelayanan pasien dan indikator fasilitas untuk identifikasi masalah, monitoring, evaluasi, dan intervensi peningkatan penggunaan obat rasional pada pelayanan kesehatan. $^{5}$

Penelitian tentang pelayanan kefarmasian berdasarkan indikator pelayanan pasien WHO telah dilakukan, antara lain di Bule Hora Hospital, Ethiopia Selatan, pada empat sarana kesehatan di Ethiopia Barat Daya, pada lima sarana kesehatan dasar di Malaysia, dan pada tiga rumah sakit di India. $6,7,8,9$ Hasil penelitian tersebut menunjukkan pelayanan farmasi belum sesuai rekomendasi WHO. Demikian pula penelitian di Indonesia tentang pelayanan kefarmasian berdasarkan indikator pelayanan pasien WHO di Kota Depok dan perbandingan antara puskesmas kecamatan di Kota Depok dan puskesmas kecamatan di Kota Jakarta Selatan menunjukkan pelayanan kefarmasian belum sesuai dengan rekomendasi WHO. ${ }^{10,11}$ $\begin{array}{ccr}\text { Pemerintah } & \text { bertanggung jawab } \\ \text { menyelenggarakan } & \text { penggunaan } & \text { obat }\end{array}$ rasional, diantaranya meningkatkan mutu pelayanan kefarmasian melalui akreditasi puskesmas. ${ }^{12,13}$ Dua dari sebelas puskesmas kecamatan di Kota Depok telah terakreditasi Kemenkes RI pada tahun 2016. ${ }^{14}$ Perbedaan status akreditasi puskesmas kecamatan memungkinkan terjadinya perbedaan pelayanan kefarmasian berdasarkan indikator pelayanan pasien WHO. Hasil penelusuran literatur, belum pernah dilakukan analisis apakah akreditasi puskesmas akan berdampak dalam perbaikan pelayanan kefarmasian yang dapat dinilai dengan indikator pelayanan pasien WHO ?. Tujuan penelitian ini untuk menilai dampak akreditasi puskesmas kecamatan terhadap pelayanan kefarmasian berdasarkan indikator pelayanan pasien WHO di Kota Depok. Indikator pelayanan pasien bagian dari indikator utama penggunaan obat rasional WHO yang dijadikan acuan Kemenkes RI dalam pelaksanaan penggunaan obat rasional. ${ }^{2}$ Hasil penelitian ini diharapkan dapat digunakan untuk perbaikan pelayanan kefarmasian agar sesuai standar WHO.

\section{METODE}

Penelitian menggunakan rancangan potong lintang (cross sectional) di 11 Puskesmas Kecamatan di Kota Depok sejak bulan Desember 2016-Februari 2017. Pemilihan puskesmas kecamatan dilakukan secara total populasi. Sampel penelitian untuk observasi lama pelayanan obat dan wawancara sebesar 25 pasien poli umum dan 5 pendamping pasien poli Manajemen Terpadu Balita Sakit (MTBS) yang berusia 18-60 tahun setiap puskesmas, sehingga total 330 orang. Sampel untuk observasi resep obat yang dibawa pasien total 330 lembar, berasal dari 25 resep obat non racikan dari poli umum dan 5 resep obat racikan dari poli MTBS per puskesmas. ${ }^{5}$

Pengumpulan data dilakukan melalui observasi dan wawancara responden, serta analisis resep obat yang diterima. Adapun parameter yang dinilai meliputi 
- Rerata waktu penyiapan dan penyerahan obat (menit). Waktu penyiapan dan penyerahan obat adalah waktu sejak pasien menyerahkan resep obat pada petugas farmasi, penyiapan obat, sampai penyerahan obat pada pasien. Rerata waktu dihitung berdasarkan pembagian waktu total penyiapan dan penyerahan obat untuk sejumlah pasien dengan jumlah pasien yang diteliti.

- Kesesuaian penyerahan obat (\%). Kesesuaian penyerahan obat adalah kesesuaian antara obat yang diresepkan dengan obat yang diserahkan pada pasien. Persentase dihitung berdasarkan pembagian sejumlah obat yang sesuai yang diserahkan pada pasien di sarana kesehatan dengan jumlah total obat yang diresepkan, dikalikan 100.

- Pelabelan obat cukup (\%). Pelabelan obat cukup adalah informasi mengenai obat yang terdapat pada wadah atau bungkus obat yang berlabel cukup berisi nama pasien serta nama, aturan pakai, dan cara penggunaan obat. Persentase dihitung berdasarkan pembagian sejumlah bungkus obat yang berlabel cukup dengan jumlah total bungkus obat yang dipersiapkan dan diserahkan, dikalikan 100.

- Pengetahuan pasien tentang penggunaan obat yang benar (\%). Pengetahuan pasien tentang pengunaan obat yang benar adalah kemampuan pasien dan pendamping pasien untuk mengulang informasi obat yang diterima, mencakup nama, kegunaan, aturan pakai, dan cara penggunaan obat. Persentase dihitung berdasarkan pembagian sejumlah pasien yang menunjukkan pengetahuan obat cukup dengan jumlah total pasien yang diwawancara, dikalikan 100.

Data hasil penelitian dianalisis menggunakan uji Mann-Whitney untuk menilai perbedaan 2 variabel skala ordinal dan uji Chi-Square untuk menilai perbedaan 2 variabel skala nominal. ${ }^{16}$

\section{HASIL DAN PEMBAHASAN}

1. Pelayaan kefarmasian berdasarkan indikator pelayanan pasien WHO

Rerata waktu penyiapan dan penyerahan obat berdasarkan rekomendasi WHO adalah lebih dari 3 menit. ${ }^{16}$ Hasil menunjukkan puskesmas kecamatan yang belum terakreditasi sesuai rekomendasi WHO sebanyak $77,8 \%$ dan puskesmas yang sudah terakreditasi $100 \%$. Semua puskesmas kecamatan di Kota Depok yang sesuai rekomendasi WHO untuk parameter kesesuaian penyerahan obat sebesar $0,0 \%$, pelabelan obat cukup sebesar $0,0 \%$ dan pengetahuan tentang penggunaan obat yang benar $0,0 \%$ dapat dilihat pada Tabel 1 .

\section{Rerata waktu penyiapan dan penyerahan obat (menit)}

Rerata waktu penyiapan dan penyerahan obat pada puskesmas yang terakreditasi $(9,8$ menit) lebih lama daripada puskesmas yang belum terakreditasi (6,7 menit). Analisis bivariat menggunakan uji Mann Whitney menunjukkan ada perbedaan bermakna antara puskesmas kecamatan yang belum dan sudah terakreditasi dengan nilai $\mathrm{p}<0,05$ ditunjukkan pada tabel 2 .

Rerata waktu penyiapan dan penyerahan obat pada puskesmas kecamatan sudah terakreditasi (9,8 menit) mendekati hasil penelitian sebelumnya pada puskesmas kecamatan di Kota Depok, yaitu 10,9 menit 10. Hasil pada puskesmas kecamatan belum terakreditasi (6,7 menit) hampir sama dengan penelitian pada Rumah Sakit di Ethiopia Barat sebesar 6,56 menit. ${ }^{16}$ Rerata waktu penyiapan dan penyerahan obat pada tiga Rumah Sakit di India 47,3 detik, dan 1,3 menit pada empat Sarana Kesehatan di Ethiopia Barat Daya., ${ }^{7,9}$ Jika dibandingkan dengan penelitian ini, maka rerata waktu penyiapan dan penyerahan obat pada Puskesmas Kecamatan yang belum dan sudah terakreditasi di Kota Depok lebih lama. 
Tabel 1. Pelayanan Kefarmasian Berdasarkan Indikator Pelayanan Pasien WHO pada Semua Puskesmas Kecamatan di Kota Depok (Desember 2016-Februari 2017)

\begin{tabular}{ccccc}
\hline $\begin{array}{c}\text { Status Puskesmas } \\
\text { Kecamatan }\end{array}$ & $\begin{array}{c}\text { Waktu penyiapan } \\
\text { dan penyerahan } \\
\text { obat (menit) }\end{array}$ & $\begin{array}{c}\text { Kesesuaian } \\
\text { penyerahan } \\
\text { obat }(\%)\end{array}$ & $\begin{array}{c}\text { Pelabelan } \\
\text { obat cukup } \\
(\%)\end{array}$ & $\begin{array}{c}\text { Pengetahuan ttg } \\
\text { penggunaan obat } \\
\text { yang benar (\%) }\end{array}$ \\
\hline Belum terakreditasi & & & & 47,30 \\
1. Bojongsari & 2,85 & 78,38 & 87,67 & 51,06 \\
2. Pancoran Mas & 5,46 & 75,53 & 88,30 & 56 \\
3. Sukmajaya & 14,13 & 83 & 83 & 69,15 \\
4. Cilodong & 3,61 & 95,75 & 86,17 & 39,42 \\
5. Tapos & 8,65 & 53,85 & 82,52 & 56 \\
6. Beji & 7,48 & 95 & 81 & 40,38 \\
7. Cinere & 6,9 & 69,23 & 79,81 & 50,57 \\
8. Limo & 2,82 & 81,61 & 81,61 & 59,80 \\
9. Sawangan & 8,53 & 94,12 & 86 & $0(0 \%)$ \\
Sesuai rekomendasi WHO & $7(77,8 \%)$ & $0(0 \%)$ & $0(0 \%)$ & \\
\hline Sudah terakreditasi & & & & 40,20 \\
1. Cipayung & 9,7 & 91,18 & 7,45 & 56,52 \\
2. Cimanggis & 9,96 & 66,30 & 83,15 & $0(0 \%)$ \\
Sesuai rekomendasi WHO & $2(100 \%)$ & $0(0 \%)$ & & \\
\hline
\end{tabular}

Tabel 2. Hubungan antara Status Puskesmas Kecamatan dan Waktu Penyiapan dan Penyerahan Obat di Kota Depok (Desember 2016-Februari 2017)

\begin{tabular}{ccc}
\hline $\begin{array}{c}\text { Status Puskesmas } \\
\text { Kecamatan }\end{array}$ & $\begin{array}{c}\text { Waktu penyiapan dan } \\
\text { penyerahan obat (menit) }\end{array}$ & $\begin{array}{c}\text { Nilai } \\
\mathbf{p}\end{array}$ \\
\hline Belum Terakreditasi & 6,7 & $\mathbf{0 , 0 0 0}$ \\
\hline Sudah Terakreditasi & 9,8 & \\
\hline
\end{tabular}

Tabel 3. Hubungan antara status Puskesmas Kecamatan dan Kesesuaian Penyerahan Obat di Kota Depok (Desember 2016-Februari 2017).

\begin{tabular}{|c|c|c|c|c|c|c|c|}
\hline \multirow{3}{*}{$\begin{array}{l}\text { Status Puskesmas } \\
\text { Kecamatan }\end{array}$} & \multicolumn{4}{|c|}{ Kesesuaian Penyerahan Obat } & & & \multirow{3}{*}{$\begin{array}{c}\text { Nilai } \\
\mathbf{P}\end{array}$} \\
\hline & \multicolumn{2}{|c|}{ Tidak Sesuai $(<100 \%)$} & \multicolumn{2}{|c|}{ Sesuai $(100 \%)$} & \multicolumn{2}{|c|}{ Total } & \\
\hline & $\mathrm{n}$ & $\%$ & $\mathrm{n}$ & $\%$ & $\mathrm{n}$ & $\%$ & \\
\hline Belum Terakreditasi & 167 & 19,4 & 692 & 80,6 & 859 & 100 & 0,785 \\
\hline Sudah Terakreditasi & 40 & 20,6 & 154 & 79,4 & 194 & 100 & \\
\hline
\end{tabular}

Keterangan: $\mathrm{n}=$ Jumlah sampel; signifikan jika nilai $\mathrm{p}<0,05$.

Berdasarkan observasi peneliti, rerata waktu penyiapan dan penyerahan obat lebih lama disebabkan jumlah pasien berlebih pada puskesmas kecamatan yang terakreditasi (Puskesmas Kecamatan Cipayung), tidak diimbangi dengan jumlah tenaga kefarmasian yang memadai.
Kekurangan tenaga kefarmasian di puskesmas berpengaruh pada kecepatan pelayanan resep. ${ }^{17}$ Menurut stadar pelayanan kefarmasian seorang apoteker dapat melayani 50 pasien rawat jalan. ${ }^{3}$ Puskesmas kecamatan yang sudah terakreditasi melaksanakan penyerahan obat disertai 
informasi sesuai standar prosedur operasional Puskesmas sehingga waktu pelayanan obat lebih lama. $^{5}$

\section{Kesesuaian penyerahan obat (\%)}

Analisis bivariat menggunakan uji ChiSquare menunjukkan tidak ada perbedaan bermakna antara puskesmas kecamatan yang belum dan sudah terakreditasi dalam kesesuaian penyerahan obat ( $p>0,05)$. Hasil tersebut ditunjukkan pada Tabel 3

Penelitian terdahulu pada empat rumah sakit di Ethiopia Barat, kesesuaian penyerahan obat sebesar $2,2 \%,{ }^{16}$ dan $46 \%$ pada tiga Rumah Sakit di India. ${ }^{9}$ Jika dibandingkan dengan penelitian ini, maka rerata persentase kesesuaian penyerahan obat pada Puskesmas Kecamatan yang belum $(80,7 \%)$ dan sudah terakreditasi $(78,7 \%)$ di Kota Depok lebih tinggi. Hasil penelitian ini lebih rendah dari penelitian terdahulu pada Puskesmas Kecamatan di Kota Depok sebesar $96,2 \%,{ }^{10}$ dan pada Rumah Sakit di Ethiopia Selatan sebesar $89,7 \% .^{6}$

Ketidaksesuaian penyerahan obat yang tinggi menunjukkan ketersediaan obat di puskesmas masih belum mencukupi kebutuhaan obat pasien. Hal ini dapat merugikan pasien, misal kurangnya dosis antibiotik menyebabkan bakteri resisten. ${ }^{18}$

\section{Pelabelan obat cukup (\%)}

Analisis bivariat menggunakan uji ChiSquare menunjukkan tidak ada perbedaan bermakna antara puskesmas kecamatan yang belum dan sudah terakreditasi dalam pelabelan obat cukup $(\mathrm{p}>0,05)$ ditunjukkan pada Tabel 4.

Penelitian terdahulu pada Puskesmas Kecamatan di Kota Depok, pelabelan obat cukup sebesar 39\%, pada empat rumah Sakit di Ethiopia Barat sebesar 28,3\%, dan pada empat Sarana Kesehatan di Ethiopia Barat Daya sebesar $70 \% .^{7,10,16}$ Jika dibandingkan dengan penelitian ini, maka persentase pelabelan obat cukup pada puskesmas kecamatan yang belum (84\%) dan sudah terakreditasi $(80,3 \%)$ di Kota Depok lebih tinggi. Hasil penelitian ini lebih rendah dari penelitian pada lima sarana kesehatan dasar di Malaysia sebesar $92 \% .^{8}$

Persentase pelabelan obat cukup lebih rendah pada puskesmas kecamatan terakreditasi karena kurangnya tenaga kefarmasian dan jumlah resep per hari yang lebih banyak (Puskesmas Kecamatan Cipayung). Hal ini menyebabkan pekerjaan pelabelan obat menjadi tidak adekuat, sehingga label obat kurang lengkap. Hasil menunjukkan persentase pelabelan obat cukup pada Puskesmas Kecamatan Cipayung paling rendah, yaitu 77,45 \% (Tabel 1). Rerata jumlah resep per hari pada Puskesmas Cipayung adalah 147 resep, sedangkan tenaga kefarmasian hanya seorang apoteker. Idealnya satu apoteker hanya melayani 50 resep per hari. ${ }^{3}$

\section{Pengetahuan pasien tentang penggunaan} obat yang benar $(\%)$.

Analisis bivariat menggunakan uji ChiSquare menunjukkan tidak ada perbedaan bermakna antara puskesmas kecamatan yang belum dan sudah terakreditasi dalam pengetahuan pasien tentang penggunaan obat yang benar $(\mathrm{p}>0,05)$ dapat dilihat pada Tabel 5.

Penelitian terdahulu pada Puskesmas Kecamatan di Kota Depok menunjukkan persentase pasien dengan pengetahuan obat yang benar sebesar $60,40 \% .^{10}$ Hasil penelitian pada empat rumah sakit di Ethiopia Barat sebesar $82 \%$ dan $74,9 \%$ pada lima sarana kesehatan dasar di Malaysia. ${ }^{8,16}$ Jika dibandingkan penelitian ini, maka persentase pengetahuan pasien tentang penggunaan obat yang benar pada puskesmas kecamatan yang belum akreditasi $(52,2 \%)$ dan sudah terakreditasi $(48,4 \%)$ di Kota Depok lebih rendah. Akan tetapi, lebih tinggi dari penelitian pada tiga rumah sakit di India sebesar 47,76 \%, dan penelitian terdahulu di Indonesia sebesar 27\%. ${ }^{9}$

Persentase pengetahuan pasien tentang penggunaan obat yang benar lebih rendah pada puskesmas kecamatan sudah terakreditasi mungkin disebabkan karena pelabelan obat yang kurang lengkap menyebabkan pasien tidak mendapatkan 


\section{Tabel 4. Hubungan antara Status Puskesmas Kecamatan dan Pelabelan Obat Cukup di Kota Depok (Desember 2016-Februari 2017)}

\begin{tabular}{|c|c|c|c|c|c|c|c|}
\hline \multirow{3}{*}{$\begin{array}{l}\text { Status Puskesmas } \\
\text { kecamatan }\end{array}$} & \multicolumn{4}{|c|}{ Kecukupan Pelabelan obat } & & & \multirow[t]{3}{*}{ Nilai p } \\
\hline & \multicolumn{2}{|c|}{$\begin{array}{c}\text { Tidak cukup } \\
(<\mathbf{1 0 0 \%})\end{array}$} & \multicolumn{2}{|c|}{$\begin{array}{l}\text { Cukup } \\
(\mathbf{1 0 0 \%}) \\
\end{array}$} & \multicolumn{2}{|c|}{ Total } & \\
\hline & $\mathrm{n}$ & $\%$ & $\mathrm{n}$ & $\%$ & $\mathrm{n}$ & $\%$ & \\
\hline Belum Terakreditasi & 142 & 16,5 & 717 & 83,5 & 859 & 100 & 0,155 \\
\hline Sudah Terakreditasi & 41 & 21,1 & 153 & 78,9 & 194 & 100 & \\
\hline
\end{tabular}

Keterangan: $\mathrm{n}=$ Jumlah sampel; signifkan jika nilai $\mathrm{p}<0,05$

\section{Tabel 5. Hubungan antara Status Puskesmas Kecamatan dan Pengetahuan Pasien tentang Penggunaan Obat di Kota Depok (Desember 2016-Februari 2017)}

\begin{tabular}{|c|c|c|c|c|c|c|c|}
\hline \multirow[t]{3}{*}{$\begin{array}{l}\text { Status Puskesmas } \\
\text { Kecamatan }\end{array}$} & \multicolumn{4}{|c|}{$\begin{array}{l}\text { Pengetahuan pasien tentang } \\
\text { penggunaan obat yang benar }\end{array}$} & & & \multirow[t]{3}{*}{$\begin{array}{c}\text { Nilai } \\
\mathbf{p}\end{array}$} \\
\hline & \multicolumn{2}{|c|}{$\begin{array}{c}\text { Tidak cukup } \\
(<\mathbf{1 0 0 \%})\end{array}$} & \multicolumn{2}{|c|}{$\begin{array}{c}\text { Cukup } \\
(\mathbf{1 0 0 \% )}) \\
\end{array}$} & \multicolumn{2}{|c|}{ Total } & \\
\hline & $\mathrm{n}$ & $\%$ & $\mathrm{n}$ & $\%$ & $\mathrm{n}$ & $\%$ & \\
\hline Belum Terakreditasi & 411 & 47,8 & 448 & 52,2 & 859 & 100 & 0,326 \\
\hline Sudah Terakreditasi & 101 & 52,1 & 93 & 47,9 & 194 & 100 & \\
\hline
\end{tabular}

informasi obat yang cukup. Hal ini sesuai dengan hasil persentase pelabelan obat cukup pada puskesmas kecamatan sudah terakreditasi lebih rendah dari yang belum terakreditasi. Jumlah pasien yang berlebih di puskesmas sudah terakreditasi (Puskesmas Kecamatan Cipayung). Ramainya pasien yang berdiri didepan loket obat menyebabkan informasi obat yang disampaikan petugas farmasi kepada pasien saat mengambil obat menjadi kurang jelas karena bising. Kondisi ini berkontribusi pada bertambahnya waktu penyerahan obat, tetapi mengurangi kualitas interaksi antara petugas farmasi dengan pasien ketika penyerahan obat. Akibatnya adalah pasien kurang memahami mengenai terapinya.

Kelebihan dan kekurangan penelitian

Peneliti tidak mencatat waktu penyiapan dan waktu penyerahan obat disertai pemberian informasi obat secara terpisah. Dengan demikian, peneliti tidak mengetahui secara pasti masing-masing waktu untuk penyiapan dan waktu untuk penyerahan obat disertai pemberian informasi obat.

Pengkajian pelayanan kefarmasian berdasarkan indikator penggunaan obat rasional WHO merupakan standar yang tinggi dan ukuran sampel tidak memerlukan adaptasi nasional. Uji lapangan menunjukkan bahwa data yang diperlukan dapat dikumpulkan dari pengamatan langsung di puskesmas. Penelitian berdasarkan indikator ini telah banyak dilakukan di berbagai negara secara konsisten, representatif, dan mudah dipahami. $^{5}$

\section{KESIMPULAN}

Pelayanan kefarmasian berdasarkan indikator pelayanan pasien WHO pada puskesmas kecamatan yang terakreditasi dan yang belum terakreditasi di Kota Depok secara umum tidak berbeda. Waktu penyiapan dan penyerahan obat pada Puskesmas Kecamatan terakreditasi lebih lama secara bermakna $(\mathrm{p}<0,05)$ dibandingkan dengan yang belum terakreditasi. Tidak ada perbedaan bermakna dalam kesesuaian penyerahan obat, pelabelan obat cukup dan pengetahuan pasien tentang penggunaan obat yang benar antara puskesmas kecamatan terakreditasi dan yang belum terakreditasi.

\section{UCAPAN TERIMAKASIH}

Kami mengucapkan terima kasih kepada Badan Pengembangan dan Pemberdayaan 
Sumber Daya Manusia Kesehatan (BPPSDMK) Kemenkes RI yang telah membantu biaya penelitian ini. Penulis mengucapkan terimakasih kepada Prof. Dr. Ratu Ayu Dewi Sartika, Apt., M.Sc, dan Prof. Dr. Sudibyo Supardi, Apt., M. Kes., yang telah mengarahkan dan memberikan saran dalam penelitian ini. Penulis juga mengucapkan terimakasih kepada Kepala Dinas Kesehatan Kota Depok yang telah memberikan izin lokasi penelitian dan pegawai seluruh puskesmas kecamatan di Kota Depok yang telah membantu pengumpulan data penelitian.

\section{DAFTAR RUJUKAN}

1. Keputusan Menteri Kesehatan Republik Indonesia Nomor 189/Menkes/SK/III/2006 Tentang Kebijakan Obat Nasional

2. Direktur Jenderal Bina Pelayanan Kefarmasian dan Alat Kesehatan. Modul Penggunaan Obat Rasional. Jakarta: Kementerian Kesehatan RI; 2011.

3. Peraturan Menteri Kesehatan Republik Indonesia Nomor 74 Tahun 2016 tentang Standar Pelayanan Kefarmasian di Puskesmas.

4. Enato EF, Chima IE. Evaluation of drug utilization patterns and patient care practices. West African Journal of Pharmacy. 2011;22(1):36-41.

5. World Health Organization, Action Programme on Essential Drugs. How to investigate drug use in Health Facilities: selected drug use indicators. Geneva: World Health Organization; 1993.

6. Mariam AH, Raghavendra Y, Bobasa EM. Evaluating rational drug use with the help of World Health Organization's core indicators in Bule Hora Hospital, Southern Ethiopia. Gaziantep Medical Journal. 2015;21(2):10813.

7. Angamo MT, Wabe NT, Raju NJ. Assessment of patterns of drug use by using World Health Organization's prescribing, patient care and health facility indicators in selected health facilities in Southwest Ethiopia. Journal of Applied Pharmaceutical Science. 2011 Sep 1;1(7):62-6.
8. Saleh K, Ibrahim MI. How rational are drugs used in Malaysian primary health care sector. Malaysian Journal of Pharmaceutical Sciences. 2006;4(1):1-12.

9. Chetia D, Nada N, Rudrapal M. Study on the use of medicines in some selected Health Care Facilities of Arunachal Pradesh. Asian Journal of Pharmaceutical and Clinical Research. 2011; 4(3): 80-81.

10. Veronika M. Analisis Pelayanan Pasien Sebagai Salah Satu Indikator Penggunaan Obat Rasional di Seluruh Puskesmas Kecamatan Kota Depok. Depok: Skripsi Program Studi Farmasi Fakultas Matematika dan Ilmu Pengetahuan Alam Universitas Indonesia, 2011.

11. Kardela W, Andrajati R, Supardi S. Perbandingan Penggunaan Obat Rasional Berdasarkan Indikator WHO di Puskesmas Kecamatan Antara Kota Depok dan Jakarta Selatan. Jurnal Kefarmasian Indonesia. 2014; 4(2):91-102.

12. Undang-Undang Republik Indonesia Nomor 36 Tahun 2009 tentang Kesehatan.

13. Peraturan Menteri Kesehatan Republik Indonesia Nomor 46 Tahun 2015 tentang Akreditasi Puskesmas, Klinik Pratama, Tempat Praktik Mandiri Dokter, dan Tempat Praktik Mandiri Dokter Gigi.

14. Dinas Kesehatan Kota Depok. Profil Kesehatan Kota Depok. http:// www.dinkes.depok.go.id, diakses Desember 2016; 2016.

15. Hastono, Priyo P. Analisis data pada bidang kesehatan. Jakarta: Raja Grafindo Persada; 2016.

16. Fereja TH, Lenjesa JL. Analysis of rational use of drugs as of facility indicators and patient care indicators practices at four selected hospitals of West Ethiopia: Policy implication. African Journal of Pharmacy and Pharmacology. 2015;9(3):48-52.

17. Maftuhah A, Susilo R. Waktu tunggu pelayanan resep rawat jalan di depo farmasi RSUD Gunung Jati Kota Cirebon tahun 2016. Medical Sains. 2016;1(1):39-44

18. Aslam A, Khatoon S, Mehdi M, Mumtaz S, Murtaza B. Evaluation of rational drug use at teaching hospitals in Punjab, Pakistan. Journal of Pharmacy Practice and Community Medicine. 2016;2(2):54-7. 